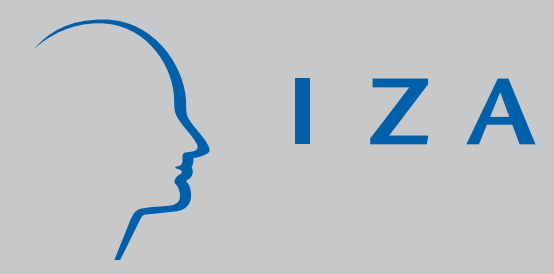

IZADP No. 1793

To Study or to Work?

Education and Labour Market Participation of Young People in Poland

Francesco Pastore

October 2005 


\title{
To Study or to Work? Education and Labour Market Participation of Young People in Poland
}

\author{
Francesco Pastore \\ Seconda Università di Napoli \\ and IZA Bonn
}

Discussion Paper No. 1793

October 2005

\author{
IZA \\ P.O. Box 7240 \\ 53072 Bonn \\ Germany \\ Phone: +49-228-3894-0 \\ Fax: +49-228-3894-180 \\ Email: iza@iza.org
}

Any opinions expressed here are those of the author(s) and not those of the institute. Research disseminated by IZA may include views on policy, but the institute itself takes no institutional policy positions.

The Institute for the Study of Labor (IZA) in Bonn is a local and virtual international research center and a place of communication between science, politics and business. IZA is an independent nonprofit company supported by Deutsche Post World Net. The center is associated with the University of Bonn and offers a stimulating research environment through its research networks, research support, and visitors and doctoral programs. IZA engages in (i) original and internationally competitive research in all fields of labor economics, (ii) development of policy concepts, and (iii) dissemination of research results and concepts to the interested public.

IZA Discussion Papers often represent preliminary work and are circulated to encourage discussion. Citation of such a paper should account for its provisional character. A revised version may be available directly from the author. 


\section{ABSTRACT}

\section{To Study or to Work? Education and Labour Market Participation of Young People in Poland ${ }^{*}$}

This paper proposes Heckprobit estimates of the determinants of labour market participation of a sample of young (15-30) Poles, controlling for the sample selection bias caused by excluding those in education. There is evidence of sample selection bias in the case of young men, suggesting that they obey more than women to economic factors in making their educational choices. Education is an important determinant of the success in the labour market. The instrumental variables used in the selection equation - the local unemployment rate, expected lifetime earnings and the opportunity cost of education - have a statistically significant impact on the probability to be in education. In contrast with several previous studies relative to mature market economies, in high unemployment voivodships young people prefer to seek a job, rather than studying. In turn, this contributes to make regional unemployment persistent.

JEL Classification: $\quad$ C35, I2, J24, P3, P52

Keywords: $\quad$ youth unemployment, education, heckprobit, Lisbon strategy, Poland

Corresponding author:

Francesco Pastore

Salita Tarsia 74

80135 - Napoli

Italy

Email: fpastore@unina.it

\footnotetext{
* An earlier version of this paper has been presented at a CERGE-EI Conference, August 2004. The author wishes to thank Ira Gang and Daniel Munich for very useful comments and Alina Verashchagina for excellent research assistance. This research was supported by a grant from the CERGE-El Foundation under a program of the Global Development Network. The Austrian Government through WIIW, Vienna, has provided additional funds for grantees in the Balkan countries. All opinions expressed are those of the author and have not been endorsed by CERGE-EI, WIIW, or the GDN.
} 


\section{To Study or to Work? \\ Education and labour market participation of Young People in Poland}

\section{Introduction}

Youth unemployment is a dramatic outcome of economic transition, becoming ever more worrisome with time passing. Most of the Central and Eastern European countries (CEECs), which became EU members in May 2004, experience a ratio of the youth to the adult unemployment rate higher than the EU average (1.9), approaching 3 in the case of Poland, the country this study focuses on. However, with few exceptions (Micklewright, 1999; Beleva et. al., 2001; O’Higgins, 2004; and Domadenik and Pastore, 2006), youth unemployment in transition countries has not received much attention in the literature.

Youth unemployment is worrisome, among other reasons, also because it contributes to make harder a dilemma that the Lisbon strategy defined by the Special EU Council of March 2000 aims to fight, by suggesting the importance for young people of investing in human capital accumulation for the future of Europe as "the most competitive and dynamic knowledge-based economy in the world capable of sustainable economic growth with more and better jobs and greater social cohesion”. Young people in CEE have to face a trade-off between continuing to invest in their own education, therefore reducing the household's budget, on the one hand; and accessing immediately the labour market, therefore contributing to the household income, but reducing their own chance to find gainful employment in the future, on the other hand ${ }^{1}$.

Contributing to the debate on the design of better educational and employment policy in transition countries is an important motivation of this research. More specifically, this paper aims to test how hard to face the aforementioned dilemma is for young people in Poland, the largest CEE country. The case of transition economies is interesting not only because of the high youth unemployment rate, but also because of the recent evolution of the market for human capital. This market has undergone tremendous tensions during the reform period. Several demand and supply side factors are at work. First, a rapid rate of technical change also adopted defensively to face the competition of productions imported from mature market economies has dramatically increased the demand for skilled labour.

From the supply side, two opposite phenomena are at work. On the one hand, the relatively high human capital endowment of the population, inherited from the previous regime, was not easy to adapt to the needs of the market economy, and was, therefore, partly "displaced” by the

\footnotetext{
${ }^{1}$ Moreover, it is a key objective of the European Employment Strategy to provide to every young person a job or training opportunity before six months of an unemployment spell elapse.
} 
emergence of market mechanisms and private initiative (see, for instance, Boeri, 2000; Ferragina and Pastore, 2005a, and the references therein). This is to be explained also by the high share of workers holding a vocational diploma only (Boeri, Köllo and Burda, 1997). On the other hand, the investment in general secondary education and in tertiary education has dramatically increased in all erstwhile transition countries, though at a different rate across countries. This is the consequence of increased payoff for skills both in terms of earnings and of employment opportunities (see Brainerd, 2000, for a cross-country study). According to anecdotal evidence, especially high-skilled young people are the winners of the transformation.

The case of Poland is typical of these changes. Poland is the transition economy experiencing the highest degree of structural change and the highest unemployment rate in the area. It adopted a Big Bang approach to the reform process, by introducing simultaneously price and trade liberalisation, together with privatisation and macroeconomic stabilisation already in the early 1990s. A massive flow of FDI has triggered the process of technological change, on the one hand, and generated the need for skill upgrading of the workforce, especially of the youngest segments, on the other hand.

Over the years, similar to other transition countries, the share of individuals with high education attainment has dramatically increased in Poland, together with the progressive abatement of the share of people with vocational secondary degrees (Boeri, 2000). Domadenik and Pastore (2006, Tab. 5 and A5) find that from 1997 to 2002 the percentage of young teenagers (15-19) in education increased from about 84 to 88, while that of young adults (20-24) increased from 20 to 31. The corresponding figures for the early 1990s were 45 and 13 percent respectively. In both cases, Poland seems to be close to the educational targets fixed within the Lisbon strategy for the year $2010^{2}$.

However, these figures raise two important issues. First is the contrast between the excellent (at least quantitative) achievement in educational attainment and the delay in bringing to reasonable levels employment and unemployment rates, which remain well below the Lisbon objectives. This raises in turn the following questions. Could the already high share of young people with a high school diploma and/or a university degree further increase if the benefits of education increased and the direct, indirect and opportunity costs reduced? Is the increase in

\footnotetext{
${ }^{2}$ The Lisbon Strategy sets specific targets to reach by 2010: a) an overall employment rate of 70\%; b) an employment rate for women of over $60 \%$; c) an employment rate of $50 \%$ among older workers; d) annual economic growth around 3\% on average. The European Employment Strategy suggests that increasing the educational level of the workforce is one of the key instruments to reach the Lisbon objectives. This requires, more specifically, to: a) bring to 12.5 the share of the adult working age population participating in lifelong learning; b) reduce to less than 10 the percentage of early school leavers; c) increase to 85 the share of 22 year-olds having completed upper secondary education; d) reduce by at least $20 \%$ (compared to 2000) the share of low-achieving 15 year-olds in reading literacy; e) raise number of graduates in the EU by at least $15 \%$.
} 
education attainment only a consequence of increased returns to education? Or are there other factors in place? Is it in particular the consequence of high unemployment rates? If the unemployment rate reduces will the share of young people in education shrink? Is an increase in education attainment sufficient per se to increase employment and reduce unemployment?

Second issue are the dramatic and persistent regional unemployment differences, which according to some authors depend, and are also fostered, by dramatic differences in the human capital endowment of voivodships. A recent strand of literature is addressing the question why urbanised regions have been able to exploit the advantages of trade integration and of capital flow from abroad. The hypothesised answer is that human capital concentration in urbanised regions is an important factor to attract FDI in advanced sectors and reduce the cost of restructuring (Lehamnn and Walsh, 1999). World Bank (2004, pp. 29-31) notes a strong negative correlation between regional unemployment and the share of workers with a high level of education attainment in Poland. In fact, these last have shorter unemployment spells. Moreover, complementarity between high technology industries and human capital generate persistence in unemployment differentials with respect to rural, depressed areas. And this result may be reinforced by migration flows, as noted in Firdmuc (2004). To what extent increasing educational attainment is reinforcing the regional pattern of unemployment?

To answer these questions, it is important to study the determinants of labour market and educational participation of young people in Poland. Of course, the final aim of accumulating human capital for a young person is increasing her/his chances to find gainful employment, as well as increase her/his lifetime earnings. However, working instead of studying cannot be considered a better choice. Conversely, starting to work early in a person's life, subtracting time to education might also be a dismal choice especially in a period of dramatic structural change. In other words, for a young person, education is a good alternative to unemployment, but also to low wage employment, helping to avoid, in many cases, long-term unemployment, poverty and social exclusion in the adult life (see, among others, Hammer, 2003, and the references therein).

To compare the individual determinants of education versus labour market participation of young people, this study proposes a Heckman PROBIT (Heckprobit) model. This is similar to the error correction procedure commonly used to control for sample selection bias in minceriantypes earnings equations, which is known as Heckit (see Heckman, 1979). In the latter type of model, a selectivity term is used to correct the estimates of coefficients in the earnings equations relative to employed workers, for the existence of jobless people - unemployed or inactive with different characteristics. Only taking into account jobless people it is possible to assess the actual impact of a given characteristics, say education, on earnings. 
The difference between a Heckit and a Heckprobit model is that, in the latter type of model, the dependent variable of the so-called main equation is not a continuous, but a dummy variable, which in this study takes a value of one if the individual is employed and zero if the individual is jobless (either unemployed or inactive) ${ }^{3}$. To control for the possible selectivity implied in excluding those involved in education, the estimates are corrected by a term simultaneously estimated by maximum likelihood using a selection equation. The dependent variable of the selection equation takes a value of one if the individual is participating to the labour market and of zero otherwise.

The study is based on the November 1997 round of the Polish labour force survey and considers a sample of individuals aged 15-30, comprising, hence, young teenagers (15-18), young adults (19-24) as well as older individuals up to the age of 30. These last are included to take into account the high share of long term unemployed and the possibility that the impact of university education was overestimated, since only the most skilled and motivated find employment shortly after obtaining their degree.

A special focus of the analysis is ascertaining the role of local labour market conditions and expected lifetime earnings on the decision to invest in further education rather than participating in the labour market. While expected lifetime earnings should affect positively the probability to invest in education, the theory and evidence on the impact of the unemployment rate on educational participation is mixed. On the one hand, some authors (Rice, 1987; 1999; Giannelli and Monfardini, 2000; and 2003) argue that the unemployment rate reduces the opportunity cost of education and therefore increases the probability that a young person is studying, rather than searching for a job. Conversely, Micklewright (1990) cannot find any significant positive effect of unemployment on education, just the opposite.

This paper innovates on the existing literature for at least two reasons. First, this is the first study to analyse the determinants of educational choices of young people in transition countries, while taking into account also the impact of local labour market conditions and expected lifetime earnings. Second, from a methodological point of view, the use of a Heckprobit model is a novelty compared to the existing literature relative to mature market economies, which generally adopts either multinomial LOGIT (MNL; see e.g. Rice, 1999) or multinomial PROBIT (MNP; see e.g. Giannelli and Monfardini, 2003) models. However, the former suffers of a serious shortcoming when analysing the youth labour market, because it assumes the hypothesis of independence of irrelevant alternatives (IIA hypothesis). This would imply that

\footnotetext{
${ }^{3}$ Note that here unemployed and inactive workers are treated as behaviourally similar, because young people experience several transitions between labour market states, and especially between unemployment and non-participation (Clark and Summers, 1982). See the methodological section for details.
} 
labour market choices be independent from education, which is hardly the case. This makes the use of MNL models inadequate to the aim. On the other hand, the MNP model does not need the assumption of independence of irrelevant alternative, but still does not allow controlling for the interdependence of the choices considered.

The rest of this paper is structured as follows. Section one gives an overview of the main features of youth unemployment in transition countries and especially in Poland. Section two describes methodology and data. A short survey of the relevant literature precedes an introduction to the Heckprobit. A discussion of the a priori about the impact of independent variables follows. Section 3 discusses the results, while the following section concludes.

\section{Youth unemployment during transition}

Economic transition is a system change involving dramatic shifts in labour demand across and within sectors and requiring, as a consequence, an important effort of labour supply, especially the youngest segment, to upgrade their skills to the needs of a market economy. This means, in turn, not only learning new technical notions, but, perhaps more importantly, facing a period of cultural change. In a way, the success itself of the reforms is up to the ability of the youngest generation to face the challenges of a market economy. Such ability depends not only on individual skills, but also on the system of incentives the economic environment is able to provide and the effectiveness of the education and training systems in furnishing opportunities

for all. There is much evidence to believe that these incentives were sometimes missing during transition (see, for a discussion, Boeri, Köllo and Burda, 1997; and Boeri, 2000).

As a consequence also of this, in most transition countries, unemployment rates of the under-25 are twice as high as or even higher than the national average. O’Higgins (2004, Fig. 5) reports that in 2001 the ratio of the youth to adult unemployment rate was (2.2) slightly higher in transition countries than in the average EU-15 (1.9). If one excludes from EU-15 the Mediterranean countries, where it is traditionally very high, then the difference is remarkable. Poland is one of the transition countries with the highest ratio at about 2.7, just below Slovenia (3.7), Romania (3.6) and Croatia (3). However, in Poland (42\%) the youth unemployment rate is the highest in the area, and much higher than in Croatia (37\%), Slovenia (17\%) and Romania (17\%).

Domadenik and Pastore (2006, Tables 5 and A5) find similar youth (15-24) to adult (2554) unemployment ratios of about 2.7 in 1997 and 2.4 in 2002. The recent reduction of the ratio (from 4 to 2 in the case of young teenagers, aged 15-19) is, in this case, not good news, because it is due to a two-time increase in the adult unemployment rate, caused, in turn, by the economic 
crisis of the late 1990s. As a consequence, the ratio reduced despite the dramatic increase in the youth unemployment rate from $26.6 \%$ to $46.8 \%$.

Domadenik and Pastore (op. cit.) find also that, different from other transition countries, the Polish unemployment rate declines only for those aged 25-34, while it increases dramatically for those aged 35-54, to slightly decline again for the over 55 . This peculiar ushaped distribution of the unemployment rate by age ${ }^{4}$ is probably due to the high degree of restructuring that the Polish economy underwent in the late 1990s, when the veto power of unions on the decision to close down the remaining state-owned and commercialised enterprises was abolished. This gave rise to conspicuous mass dismissals, involving also numerous primeaged workers (World Bank, 2001).

The picture was slightly different in 1997. Before the recent surge in unemployment, the young teenagers had double the unemployment rate of young adults and more than three times the average unemployment rate. Moreover, in 1997, the distribution of the unemployment rate by age was similar to that of other transition countries, as it decreases constantly, to increase again only for the over 55.

About 9.6 percent of workers are employed on a temporary basis, a share similar to other transition countries. In 1997, the same figure was only 4.3 percent, which is suggestive of an increasing degree of flexibility of the Polish labour market under this respect.

Typically, high youth unemployment comes along with high youth long-term unemployment, and transition countries are no exception under this respect. O'Higgins (2004) reports that, in 2001, more than 50 percent of young Poles remained unemployed for more than 6 months once entering the unemployment pool. The corresponding figure for the population aged 25-54 was almost 70 percent. Albeit lower than the adults' share of long-term unemployment, that of young people is not less worrying. In fact, on the one hand, it is true that youth long-term unemployment is to some extent physiological, since it depends on the younger age of the latter group; and, transitory, being related to the tendency of young people to search for the best match. However, in several cases it has a long-lasting effect, being conducive to social exclusion in the adult life as well as, at a macroeconomic level, contributing to make persistent a country's unemployment rate.

4 Newell and Pastore (1999) also find remarkable peculiarities of the age distribution of unemployment in Poland. They estimate Cox models of the probability of job loss separately for the highest and the lowest unemployment regions in 1994, a period of dramatic structural change. They allowed a spline in age with slope changes at 25, 35 and 45. One of the most important differences between the low and high unemployment voivodships is that middle-aged workers in high unemployment regions have almost no greater job security than young workers. This is in clear contrast to the situation in the low unemployment regions where young workers are much more likely to enter unemployment than their older colleagues are. Thus, in high unemployment regions the risk of unemployment does not diminish with age, as is normally the case in Western economies (see Arulampalam and Stewart 1995). 
Unemployment is not evenly distributed among young people also in transition countries. Some groups of young persons are more likely to be unemployed than others (some classical examples are ethnic minorities, disabled individuals, unskilled workers, etc). In addition, despite the sharp decline in their participation rates, school leavers without work experience are the group hardest hit by unemployment. Last but not least, not surprisingly, the unemployment rate is inversely related and the participation and employment rates are directly related to the level of education attainment.

\section{Methodology and data}

\subsection{The state of the art}

Demand for education and school-to-work transitions of young people have received much attention from the economics of education and the labour economics literature, starting at least from the seminal contributions of Blinder and Weiss (1976) and Heckman (1976). They are among the earliest authors to adopt a simultaneous approach for the study of labour supply and educational decisions of young people. Their model assumes that the impact of education is not only on earnings, but also on employment opportunities. With the availability of longitudinal data-sets, some authors, such as Keane and Wolpin (1997), have attempted to simulate the initial career of a sample of young men provided they maximise utility coming from different states: attending school, working and choosing a given occupation.

However, in the more frequent case when only cross-section data is available, two alternative approaches dominate research in the field, namely the MNL and the MNP models. Rice (1999), Denny and Harmon (2000), Nguyen and Taylor (2003) and Caroleo and Pastore (2003), for instance, use a MNL framework to study the probabilities of being employed, rather than unemployed, inactive or in education. This approach requires the heroic assumption that the alternatives faced by young people are mutually exclusive, the hypothesis of independence of irrelevant alternatives (HIIA).

Giannelli and Monfardini (2000; and 2003) and Davia (2004) are examples of papers that release the HIIA, implicit in a MNL model, by adopting a MNP approach ${ }^{5}$. In particular, Giannelli and Monfardini (2003) study the decisions of Italian young adults (18-30) both related to education versus work and the option to remain at parental home. They focus on the effect of

\footnotetext{
${ }^{5}$ One reason why the MNP is less frequent is its computational difficulty.
} 
labour market conditions (affecting income and employment expectations) and family background characteristics together with housing costs.

In the only study available on transition economies, Domadenik and Pastore (2006) apply MNL analysis to the study of the determinants of labour market participation and education of young people in Poland and Slovenia in 1997 and 2002. They consider six choices: permanent employment, temporary employment, self-employment, unemployment, education, training and inactivity. Their findings point to tertiary education as an important buffer against the risk of unemployment. Participation into training programmes reduces the risk of being unemployed, but not of being inactive. Gender differences among young people in the probability to be employed on a permanent basis are important in Poland, but they tend to abate in recent years. Finally, family break-ups lower the probability to find employment in both countries.

\subsection{The Heckman probit model}

The assumption of the modelling strategy pursued here is that the primary decision of young people is whether to participate to the labour market or study. Only at a later stage, once decided to leave education, the young person will seek permanent employment. This would suggest refuting both a MNL and a MNP $\operatorname{model}^{6}$, and to opt for a Heckman correction procedure, which in this case is indeed the so-called Heckman PROBIT (Heckprobit), since the variable detecting the labour market state is binary and takes a value of 1 for employment and of 0 for joblessness, where joblessness includes unemployment and inactivity. Introduced for the first time by Van de Ven and Van Pragg (1981), the Heckprobit allows estimating PROBIT models when there is suspect of sample selection bias. In the case under scrutiny, if the sample of individuals participating in the labour market is systematically different from that of those who are in education, coefficients of determinants of success in finding employment might be biased.

The unemployed and inactive individuals are pooled together because in the case of young people such labour market states are often very similar. In the seminal paper by Clark and Summers (1982), young people have a high degree of turnover and the transitions from unemployment to employment are not less sizeable than those from inactivity to employment. Also the transitions from unemployment to inactivity are high. Poterba and Summers (1995) find that the differences between unemployment and inactivity are weak, causing dramatic classification errors. This is likely to occur especially among the youngest segment of the

6 Other natural alternatives would be a conditional LOGIT model (which requires detailed longitudinal data able to individualise the time of exit from education) and a bivariate PROBIT model (which is generally used for evaluation of the gross impact of pro-active schemes). 
population. Of course, this assumption is to be taken with the due caveats, keeping in mind the contribution by Flinn and Heckman (1983). They suggest that the behaviour of individuals who are inactive because they are disabled, retired or otherwise unable to work is different. For this reason, the group of those who declare not to work because they are unable to work have been excluded from the analysis, whereas the disabled who do not declare to be unable to work have been included in the analysis.

From an analytical point of view, the Heckprobit model assumes the existence of an underlying relationship, also called latent equation:

$\mathrm{Yj}^{*}=\mathrm{Xj} \beta+\mathrm{u}_{1 \mathrm{j}}$

such that the binary outcome is observed, which is mirrored by a PROBIT equation:

$\mathrm{Y}_{\mathrm{j}}^{\text {probit }}=\left(\mathrm{Yj}^{*}>0\right)$

In this paper, this binary outcome corresponds to employment and joblessness. The dependent variable, however, is not always observed. To capture the relevant effect on the standard PROBIT results the corresponding selection equation is introduced:

$$
\begin{aligned}
& \mathrm{z}_{\mathrm{j}} \gamma+\mathrm{u}_{2 \mathrm{j}}>0 \\
& \text { such that } \\
& \mathrm{Y}_{\mathrm{j}}^{\text {select }}=\left(\mathrm{z}_{\mathrm{j}} \gamma+\mathrm{u}_{2 \mathrm{j}}>0\right) \\
& \mathrm{u}_{1} \sim \mathrm{N}(0,1) \\
& \mathrm{u}_{2} \sim \mathrm{N}(0,1) \\
& \operatorname{corr}\left(\mathrm{u}_{1} \mathrm{u}_{2}\right)=\rho
\end{aligned}
$$

When $\rho \neq 0$, i.e. there is correlation between error terms of main and participation equation, the standard PROBIT model will produce biased results. The Heckprobit procedure instead is intended to correct for selection bias, and to provide consistent, asymptotically efficient estimates for all the parameters in the model.

\subsection{Data and variables}

The estimates are based on the November 1997 wave of the Polish labour force survey (LFS), a nationally representative large micro-data set providing detailed and accurate information on various aspects of labour market participation of the Polish population, such as wages and other sources of income of the individual and the household, the ILO definition of unemployment and the city of residence.

From the point of view of this study, the main shortcoming of LFS data is the lack of information on family background, which is usually found to be an important determinant of the 
educational choices of young people, together with expected incomes of high education and unemployment (see e.g. Rice, 1987; 1999; Giannelli and Monfardini, 2000; and 2003). For instance, it is impossible to obtain information on the educational level of the parents of all the individuals ${ }^{7}$. However, the PLFS asks respondents a specific question on the main source of the household income. This allows detecting at least one important aspect of the family background able to affect, according, for instance, to Rice (1987) the decision of young men, if not women, to invest in post-compulsory education in the UK.

Table AI in the Appendix provides a detailed description of the variables used in the estimates. The sample has been restricted to about 16,000 young people aged 15-30, grouped in employed, jobless and in education ${ }^{8}$. These states are treated as mutually exclusive. Following the ILO definitions, employed individuals have been identified as all those declaring to have some type of paid work during the reference week, independent of whether they are also students or not ${ }^{9}$. A specific question allows identifying whether the individual is a student. The rest is considered jobless. As discussed in the previous section, the jobless group includes unemployed and inactive, except for a small number of individuals declaring that they do not work because they are unable to work. These last have been dropped from the sample.

The independent variables in the main and in the selection equations include different types of education attainment, age (as a proxy for work experience) and its square value, gender, civil status, relation to the household head, the main source of income of the household and the size of the town where he lives. The expectation is that the chances of successfully find a job depend on education and work experience, which, according to the model of investment in human capital, are factors able to affect the productivity of individuals, controlling for the other available variables. Also the main source of income of the household is an interesting background variable able to disentangle the economic incentives the household gives to young people. The reference group in the main equation is constituted of married men aged 15-30, with primary education or below, living with their parents in rural areas and whose household lives out of income coming from private farming.

Similar to the Heckit, also in the Heckprobit, the selection equation should include the same independent variables that are in the main equation (and are defined also for the selection equation), plus some additional instrumental variables, which are supposed to affect the

\footnotetext{
${ }^{7}$ It is indeed possible to obtain information on the family background of many young people from LFS data (as well as household survey data). This requires merging the database relative to individuals with that relative to households. However, while the percentage of attrition might by high, this strategy is unsuccessful in the case of young people living alone, whose share is high in most countries.

${ }^{8}$ Note that eight graduate students have been included among those in education.

${ }^{9}$ Note that 237 individuals study and work, while 51 study and are jobless.
} 
dependent variable of the selection equation, but not that of the main equation. In this case, the instrumental variables should be able to affect participation in education, but not labour market participation. The variables used here as instruments to identify the selection equation include expected lifetime earnings of further education, the local unemployment rate and the opportunity cost of studying.

Expected lifetime earnings are measured for high school diploma and university degree according to the procedure suggested, among others, in Giannelli and Monfardini (2003). In other words, two different out-of-sample earnings equations were estimated for university and high school graduates using a sample of women aged 31-60 (the retirement age) and of men aged 31-65, using the Heckit procedure to control for sample selection bias. Table A1 in the Appendix contains a more detailed description of the procedure adopted to construct these variables, while Table A2 reports the results of the Heckit estimates. The interpretation of the impact of expected earnings on labour market participation is straightforward. The expected sign is negative, since the higher are expected earnings of further education, the higher is the probability that a young person prefers to attend school or university programmes rather than being in search (successfully or not) for a job.

The previous literature is ambiguous as to the impact of local unemployment on educational participation. On the one hand, some authors find that the proportion of the age cohort remaining in full-time education following completion of compulsory schooling is counter-cyclical and, therefore, positively correlated with the rate of unemployment over the long-run (see Pissarides, 1981; Whitfield and Wilson 1991; McVicar and Rice, 2001). The argument is that the higher is the local unemployment rate, taken as a proxy of local labour market conditions, the lower is the opportunity cost of investing in education, since the lower is also the chance to find employment if not at school. As a consequence one would expect high unemployment regions to have a relatively bigger number of people enrolled into education, all other things being equal. This is sometimes called the "parking theory", since it implies that young people "park" themselves at the university while waiting for a job offer to come. Nonetheless, the evidence based on individual level data is mixed on this variable: while some authors (Rice, 1987; 1999; Giannelli and Monfardini, 2000; and 2003) confirm the results of studies based on aggregate data, others authors (see e.g. Micklewright, 1990) instead either do not find any significant effect or find a negative relationship. One reason why the local unemployment rate might not increase, but rather reduce the number of people enrolled in high education might be the lower expected earnings of post-compulsory degrees in high unemployment regions. In fact, assuming that capital and skills are complementary, if high unemployment regions are also backward, it is likely that the demand for skilled labour is lower 
than in low unemployment regions. As a consequence, low unemployment regions could provide not only a lower opportunity cost, but also a lower expected benefit of investment in further education. Moreover, backward high unemployment regions might also have a lower supply of education, often also of low quality, which might increase the costs of education. Following the former (latter) hypothesis, the expected sign of the coefficient of this variable in the selection equation is negative (positive), since ceteris paribus with unemployment increasing young people should prefer to study rather than searching for a job. The overall impact of the two variables considered until now cannot be predicted ex ante and is matter of empirical investigation.

The unemployment rate has been used either as a continuous variable - the 1997 voivodship unemployment rate by gender for those aged 30 or below - or as a set of dummy variables representing the low, medium and high unemployment voivodships. As described in more detail in Table A1 in the Appendix, the Polish voivodships have been ranked by their youth unemployment rate of men and women in 1997. Low, medium and high unemployment voivodships are the voivodships with the lowest, medium and highest youth unemployment rate, representing each about one third of the sample population. More detailed classifications have also been used. The preferred one is constructed by dividing the Polish voivodships in five groups each representing about one twentieth of the sample. The dummy variables have been preferred to the continuous variable, following the argument that macro-variables generate bias when included in estimates based on individual level data (Moulton, 1991).

Finally, the product of the average hourly wage and the probability to find employment by age measures the opportunity cost of studying. The expected sign is positive, since the higher is the opportunity cost of studying, the higher is the probability to leave the educational system and to be in search for a job.

\section{Results}

Table 1 reports descriptive statistics of the sample. Slightly more than $60 \%$ of young Poles are employed or jobless, while the rest are students. The jobless are $28.7 \%$, of which $19.2 \%$ are unemployed.

While the percentage of women who are studying is slightly higher than that of men, these last are more successful than their female counterparts in finding a job. About $40 \%$ of the women who are not studying remain jobless; the corresponding figure for men is only $18.1 \%$. In addition, the unemployment rate of women (22.1\%) is much higher than that of men (15.2). This fact is probably related with women' reproductive activities in the household. In fact, the 
share of married women in the sample is much greater than that of men; though, under other respects women have very similar characteristics to men. This suggests that the different success in the labour market of men and women essentially depends on differences, which are unobserved in the data available. As noted in a previous section, the Polish labour force survey, in fact, does not provide sufficiently detailed information on the household characteristics.

Similar to several South European countries (see, for a comparison of EU countries, Hammer, 2003), in the catholic Poland, a large share of young people (68.9\%) live with their parents up to the age of 30 . This is especially the case of men (73.3\%). These percentages cannot be fully explained by attendance of university programmes, as it is the case of Italy, for instance. In Poland, 4-5 years on average are sufficient to obtain a university degree, the share of college attendance is not highest and the number of dropouts is relatively low. The high share of the population living in rural areas, where the household is still enlarged, as well as the high cost of housing in urban areas contribute to explain the phenomenon under discussion.

\section{[Table 1 about here]}

Table 2 reports the results of three heckprobit estimates relative to the entire sample, to men and women. Note that the main equation precedes the selection equation, while auxiliary information and main statistical tests are reported in the last rows of the table.

Overall fit of the model and sample selection hypothesis. The significance level of the coefficient of the artrho and the Wald test of independent equations concur to suggest that the null hypothesis of no correlation between error terms of main (participation) and selection (education) equation is rejected for the entire sample and for men, but not for women. In other words, any estimate of the determinants of the probability to successfully find a job without controlling for sample selection bias would turn biased results in the case of men, but not in that of women.

The case of women is not particularly surprising. On the one hand, one might think that the labour market decisions of women are less influenced by economic reasons, and that if they choose to study, they do not look only at the benefit and cost of education (see also Rice, 1987). On the other hand, it is also likely that some important determinants of the labour market decisions of young women, such as maternity, are not fully controlled for in the data available ${ }^{10}$.

[Table 2 about here]

${ }^{10}$ Only women on maternity leave can be identified. No information is provided on the number of children, though. 
Main equation. Education attainment is an important determinant of success in the labour market. All the coefficients are statistically significant, with the only exception of vocational secondary school for men, which suggests that every group fares better than the baseline group with primary education or below. University education is more important than other types of education. In addition, there are statistically significant differences between those with a high and those with a low secondary school diploma.

The return to education is higher for women, confirming a stylised fact of studies on the determinants of earnings differentials by gender, namely that the returns to education are higher for women despite the existence of sizeable gender gap (Psacharopoulos, 1994). One possible explanation of this finding is the higher motivation of women with a high degree of education attainment compared to their male counterparts.

Age is an important determinant of the probability to be employed for men, but not for women. The profile is concave, as shown by the negative coefficient of the squared term. This suggests that the older is a young men, the higher is his probability to be employed, although such probability exhibits decreasing returns.

Participation into training in the past three months is not a significant determinant of success in finding employment, although it affects the probability to participate to the labour market, as shown by the coefficient in the selection equation.

Women are worse off, which confirms a finding of Domadenik and Pastore (2006) based on multinomial LOGIT analysis. Poland is one of the countries where women experience a disadvantage already early in their working career, which is common in South European countries, but not so much in Nordic and also in Eastern European countries (O’Higgins, 2004).

All other things being equal, single women have a higher probability to find employment than married (divorced or widowed) women, but for men the opposite holds true. Single men are less likely to be working than the rest. Recall that people marry as early as just above their twenties in Poland (see UNICEF for statistics relative to 1997) and soon after they have children. Nonetheless, this average age of marriage and first birth is declining with time passing and it is likely that this effect is weakening in recent years.

For similar reasons, being a household head reduces the reservation wage and increases the probability of employment for men, but not for women. Women who are also household head are less likely to find a job than those living with parents, especially if they are non-single. This is probably related with the presence of children.

Interestingly enough, the most successful job seekers are those young people whose household is living out of income coming from private farming. This is a typical feature of Poland, where private agriculture, often constituted of small land plots, has always existed also 
during the communist era, representing an important reservoir of employment in the posttransition high unemployment period. This finding is confirmed also by the set of variables relative to the city of residence. The smaller the city of residence, the lower is the probability to find employment. However, in urban areas it is generally less easy for a young person to find employment than in rural areas. In turn, this is evidence in line with the conclusions of the literature on regional unemployment in Poland and other transition countries according to which big cities and rural areas offer much greater chances to find employment than small towns. In fact, traditionally, the group of low unemployment regions includes both urban and rural regions (for a survey of the literature on regional unemployment in new EU members, see Ferragina and Pastore, 2005b).

Selection equation. Generally speaking, the higher is the educational degree already achieved the higher is the probability to participate to the labour market. Having a vocational secondary education diploma seems to reduce the probability to participate in the labour market and to increase that of investing in further education. This coefficient might mirror the tendency of young people with vocational secondary diplomas to continue their studies to achieve a more general level of education.

The age profile of labour market participation is steep, with very high coefficients, but still concave for women, since with time passing young people tend to finish their studies.

As already noted looking at descriptive statistics, gender differences in educational choices are less important than those in terms of the probability of success in the labour market. As shown by the gender coefficient, the ceteris paribus probability for a young man to remain in education is not statistically different from that of a woman.

Single individuals prefer to continue to invest in education rather than searching for a job, a result, which is symmetric to that found when looking at the main equation. This is obviously related also to the fact that the decision to work and that to establish a new household are strongly related to each other. Similarly, and on the opposite verge, a household head tends to search for a job, rather than investing in education.

Households holding private farms provide young people with a lower incentive to study, since perhaps they provide them with easier access to gainful employment. Similarly, living in urban areas significantly increases the probability to invest in further education. This might be due not only to a demand-side, but also to a supply-side effect, since, in urban areas, the supply of education is greater. Overall, this finding strengthens that discussed in the next section regarding the negative impact of unemployment on investment in human capital accumulation. 
The instrumental variables. The instrumental variables have the expected sign and are generally statistically significant. Experimenting with variables ${ }^{11}$ suggests that the estimated coefficients are robust to changes in the specification adopted.

Expected lifetime earnings of university education have a statistically significant positive impact on the probability to be in education rather than participating to the labour market. Instead, though always positive, the expected earnings of successfully completing high school is statistically significant only in the case of men. Wald tests cannot reject the null hypothesis that the two coefficients are equal. This is contrary to what one would expect considering the wage premium of university on high secondary education in Poland, especially for women, but is consistent with the idea that economic incentives to further education are evenly distributed across qualifications as expected in a well-functioning market for human capital.

Overall, these results confirm that, similar to that of other new EU members, the Polish economy provides strong economic incentives to invest in post-compulsory education, which, in turn, contributes to explain the aforementioned remarkable increase in the level of education attainment the country has recently experienced.

Nonetheless, the impact of expected earnings on investment in education is smaller in the case of women. This finding is in line with the previous observation that economic incentives are less important in the case of women, or perhaps that they should be measured in a different way, by looking, for instance, at the reproductive activities of women in the household.

Furthermore, the estimates proposed here suggest that, although not always highly significant, the ceteris paribus impact of unemployment on educational participation is consistently negative, not positive ${ }^{12}$. A high local unemployment rate does not represent an incentive to invest in further education, just the opposite.

Note also that such impact is inversely u-shaped: with unemployment increasing, in fact, participation into education increases first and then reduces. This interesting result is confirmed in all the estimates. To further investigate on this finding, Table 3 presents several estimates based on two sets of unemployment dummies. The former set of estimates uses the average youth unemployment rates, whereas the latter uses different youth unemployment rate for men and women. These regressors are used in two types of model. Model (1) is the same as in Table 1 , while dummies measuring the population size of the place of residence are dropped from Model (2). Inspection of the table clarifies that the non-linearity is especially strong in the case of women and, as shown by the results of Model (2), seems to depend only in part on interaction

${ }^{11}$ Results of such experiments are available on request.

${ }^{12}$ This finding is confirmed also by use of different unemployment measures. In omitted estimates, the voivodship unemployment rate gives a coefficient of 0.49 for the entire sample, 0.95 for women and 0.11 for men. It is highly significant only in the case of women. 
with the place of residence. Wald tests are used to test for statistically significance of the difference between the coefficients. They cannot always reject the hypothesis that differences are significant, but they do reject this hypothesis in some cases. In the estimates relative to the entire sample, differences are statistically significant between U30(2)_2 and U30(2)_4, but not in the other cases. In the case of women, the tests reject the hypothesis that U30(2)_2 and U30(2)_3 are equal. In the case of men, the tests cannot reject the hypothesis that the coefficients of U30(2)_3 and U30(2)_4 are equal and of U30(2)_2 and U30(2)_5 are equal, but rejects the hypothesis that these two pairs are equal to each other.

\section{[Table 3 about here]}

In other words, in high youth unemployment voivodships, the probability for a young person to be in education is lower than in low youth unemployment voivodships, suggesting that unemployment causes a reduction in the benefit of education which overweighs that in the opportunity cost of education. This finding goes contrary to expectations based on part of the literature relative to some mature market economies (see the already mentioned Rice, 1987; 1999 for the UK; and Giannelli and Monfardini, 2000; and 2003 for Italy $)^{13}$. However, it is in line with part of the literature (see e.g. Micklewright, 1990) on mature market economies and that on Poland, which shows the existence of strong negative correlation between the local unemployment rate and the level of education of the local workforce (World Bank, 2004).

Consider again the interaction between local unemployment and the urban/rural divide. High unemployment areas are often also rural areas, and nevertheless the coefficient of high local unemployment is still statistically significant even after controlling for the place of residence. Therefore, the incentive to invest in education is the lowest in rural high unemployment areas. This is likely to contribute to increase the spatial unemployment gap, if the level of human capital endowment is to be taken as an important factor of economic growth. This is a major reason of concern: without interventions aimed at equilibrating the educational divide between rural high unemployment and urban low unemployment voivodships, pursue of the Lisbon strategy is bound to reinforce the already dramatically persistent regional unemployment pattern.

Finally, in omitted estimates, the opportunity cost of education is positive as expected and highly significant in the case of the entire sample (with a coefficient of 0.52) and in the case of women (0.56), and only significant at the $10 \%$ in the case of men (0.38). However, this variable

${ }^{13}$ One possible explanation of this difference might be the absence here of controls for family background. Nonetheless, if family background is more favourable to investment in education in low unemployment areas, this is already suggestive of a negative impact of unemployment on education attainment. 
is not included in the preferred specification of Table 2 because of a suspect of collinearity with the unemployment rate.

\section{Concluding remarks}

This paper aims to contribute to the important issue of identifying subgroups of young people with high probability to leave school, therefore reducing their chance of finding gainful employment in the long run. Fine targeting educational reforms and ALMP on these specific groups would enhance their effectiveness, in a time of hard state budget constraint.

To reach the aim, this paper proposes Heckprobit estimates of the probability to find employment rather than being jobless of a sample of Polish young (15-30) people, controlling for sample selection bias caused by the presence of people involved in further education. There is evidence of sample selection bias in the case of young men (but not of women), confirming the a priori expectation that the two choices: employment/joblessness and job search/investment in education are not independent.

The results confirm the role of education in explaining the success in the labour market of young people. Also factors that reduce (increase) the reservation wage tend to increase (reduce) the probability of employment. Being a household head, for instance, increases the chances of being employed. Woman are more likely to continue education and less likely to find a job thereafter.

The instrumental variables used in the selection equation - the local unemployment rate, expected lifetime earnings and the opportunity cost of education - have a statistically significant impact on the probability to be in education. In contrast with several previous studies relative to mature market economies, high unemployment voivodships provide a disincentive to further education, and an incentive for job search. Overall, the analysis confirms that rural high unemployment areas contribute less to the increase in education attainment experienced recently in Poland also under the auspices of the Lisbon strategy. In turn, this contributes to make regional unemployment persistent. Less surprising is the positive impact on the decision to invest in further education provided by expected lifetime earnings. 


\section{References}

Arulampalan, W. and M. B. Stewart (1995), "The determinants of individual unemployment durations in an era of high unemployment”, The Economic Journal, Vol 105, issue 405, pp. 321-332.

Beleva, I., A. Ivanov and N. O’Higgins and F. Pastore (2001), "Targeting Youth Employment Policy in Bulgaria” (2001), Economic and Business Review, Vol 3, No 2, pp. 113-135.

Blinder, A.S., Weiss, Y. (1976) "Human Capital and Labour Supply: a Synthesis", The Journal of Political Economy Vol 84, No 3, pp. 449-472.

Boeri, T. (2000), Structural Change, Welfare Systems, and Labour Reallocation, Oxford University Press, Oxford.

Boeri, T., Köllo J. and Burda M. (1997), “Labour Market in Central Europe and the EU Enlargement”, A CEPR / IEWS Conference, Portoroz, June, pp. 13-15.

Brainerd, E. (2000), "Women in Transition: Change in Gender Wage Differentials in Eastern Europe and FSU”, Industrial and Labour Relations Review, Vol 54, No 1, pp. 139-162.

Caroleo, F. E. and F. Pastore (2003), "Youth Participation in the Labour Market in Germany, Spain and Sweden”, in T. Hammer (op. cit), Chapter 7, pp. 115-141.

Clark, K. B. and L. H. Summers (1982), "The Dynamics of Youth Unemployment”, in Summers, L. H. (1990), Understanding Unemployment, MIT Press, Cambridge, Mass..

Davia, M.A. (2004), "Tackling Multiple Choices: A Joint Determination of Transitions out of Education and into the Labour Market across the European Union”, ISER discussion paper, n. 22.

Denny, K., Harmon, C. (2000) "The Impact of Education and Training on the Labour Market Experiences of Young Adults”, Institute for Fiscal Studies working paper, No 00/08, London, United Kingdom.

Domadenik, P. and F. Pastore (2006), "The Impact of Education and Training Systems on the Labour Market Participation of Young People in CEE Economies. A Comparison of Poland and Slovenia”, forthcoming in International Journal of Entrepreneurship and Small Business, Vol 3, No 1 .

Ferragina, A. and F. Pastore (2005a), "Factor Endowment and Market Size in EU-CEE Trade. Would Human Capital Change the Actual Quality Trade Patterns?”, Eastern European Economics, Vol 43, No 1, pp. 3-33.

Ferragina, A. and F. Pastore (2005b), "Mind the Gap. Unemployment in the New EU Regions”, IZA discussion paper, No 1565.

Fidrmuc, J. (2004), "Migration and Regional Adjustment to Asymmetric Shocks in Transition Economies”, Journal of Comparative Economics, Vol 32, No 2, pp. 230-247.

Flinn, C. J. and J. J. Heckman (1983), "Are Unemployment and Out of the Labour Force Behaviourally Distinct Labour Force States?”, Journal of Labour Economics, Vol 1, No 1, pp. 28-42.

Giannelli, G.C., Monfardini, C. (2000), "A Nest or a Golden Cage? Family Co-Residence and Human Capital Investment Decisions of Young Adults”, International Journal of Manpower, Vol 21, No 3/4, pp. 227-245.

Giannelli, G.C., Monfardini, C. (2003), "Joint Decisions on Household Membership and Human Capital Accumulation of Youths. The Role of Expected Earnings and Local Markets”, Journal of Population Economics, Vol 16, No 2, pp. 265-286.

Hammer, T. (2003), Youth Unemployment and Social Exclusion, The Policy Press, Bristol.

Heckman, J.J. (1976), “A Life-cycle Model of Earnings, Learning and Consumption”, The Journal of Political Economy, Vol 84, No 4, part 2: Essays in Labor Economics in honor of H. Gregg Lewis, S11-S44.

Heckman, J. (1979), “Sample selection as a specification error”, Econometrica, vo. 47, No 1, pp. 131-161. Keane, M.P., Wolpin, K.I. (1997), “The Career Decisions of Young Men”, The Journal of Political Economy, Vol 105, No 3, pp. 473-522.

Lehmann, H. and P. P. Walsh (1999), "Gradual Restructuring and Structural Unemployment in Poland: A Legacy of Central Planning”, LICOS discussion paper, n. 78, Katholieke Universiteit Leuven.

McVicar, D. and Rice, P.G. (2001), "Participation in further Education in England and Wales: An Analysis of Post-War Trends", Oxford Economic Papers, Vol 53, No 1, pp. 47-66.

Micklewright, J. (1990), “Unemployment and Early School Leaving”, Economic Journal, Vol 100, n. 400, pp. 163-169.

Micklewright, John (1999), “Education, Inequality and Transition”. Innocenti Working Papers, ESP No. 74. Florence: UNICEF Innocenti Research Centre. 
Moulton, B.R. (1991), “An Illustration of a Pitfalls in Estimating the Effects of Aggregate Variables on Micro Units”, Review of Economics and Statistics, Vol 72, No 2, pp. 334-338.

Newell, A. and F. Pastore (1999), "Structural Change and Structural Unemployment in Poland", Studi Economici, Vol 54, issue 69, No 3, pp. 81-100.

Nguyen, A.N., Taylor, J. (2003) "Post-high School Choices: New Evidence from a Multinomial Logit Model”, Journal of Population Economics, Vol 16, No 2, pp. 287-306.

O’Higgins, N. (2004), "Recent Trends in Youth Labour Markets and Youth Employment Policy in Europe and Central Asia”, CELPE discussion papers, n. 85.

Pissarides, C.A. (1981), "Staying on at School in England and Wales”, Economica, Vol 48, issue 192, pp. 345-363.

Poterba, J.M. and L.H. Summers (1995), "Unemployment Benefits and Labour Market Transitions: A Multinomial Logit Model with Errors in Classification”, Review of Economics and Statistics, Vol 77, No 2, pp. 207-216.

Psacharopoulos, G. (1994), “Returns to Investment in Education: a Global Update”, World Development Vol 22, No 9, pp. 1325-1343.

Rice, P.G. (1987), "The Demand for Post-Compulsory Education in the UK and the Effects of Educational Maintenance Allowances”, Economica, Vol 54, issue 216, pp. 465-475.

Rice, P.G. (1999), “The Impact of Local Labour Markets on Investment in further Education: Evidence from the England and Wales Cohort Studies”, Journal of Population Economics, Vol 12, No 2, pp. 287-312.

Van de Ven, W.P.M.M. and B.M.S. Van Pragg (1981), “The demand for deductibles in private health insurance: A probit model with sample selection”, Journal of Econometrics, Vol 17, No 2, pp. 229-252.

Whitfiled, K. and R.A. Wilson (1991), "Staying-on in Full-Time Education: The Educational Participation Rate of 16-year-olds”, Economica, Vol 58, issue 231, pp. 391-404.

World Bank (2001), Poland-Labor Market Study: The Challenge of Job Creation, World Bank Country Study, March.

World Bank (2004), Poland. Growth, Employment and Living Standards in Pre-Accession Poland, Report, No 28233. 


\section{Tables}

Table 1. Descriptive statistics (15-30)

\begin{tabular}{|c|c|c|c|}
\hline Variable & All & Women & Men \\
\hline Employed/jobless of which: & 61.8 & 61.0 & 62.5 \\
\hline Employed & 71.3 & 60.3 & 81.2 \\
\hline Jobless & 28.7 & 39.7 & 18.1 \\
\hline Students & 38.2 & 39.0 & 37.5 \\
\hline \multicolumn{4}{|l|}{ Education attainment } \\
\hline University degree & 3.9 & 4.7 & 3.1 \\
\hline Post-secondary school diploma & 2.4 & 3.8 & 1.0 \\
\hline General high secondary school & 17.4 & 18.8 & 15.9 \\
\hline Vocational high secondary school & 9.0 & 12.6 & 5.5 \\
\hline Low secondary school & 28.3 & 22.1 & 34.4 \\
\hline Primary school & 37.7 & 36.9 & 38.4 \\
\hline Below primary & 1.4 & 1.1 & 1.6 \\
\hline Age & 21.7 & 21.7 & 21.7 \\
\hline $\operatorname{Age}^{\wedge} 2$ & 491.6 & 492.9 & 490.2 \\
\hline Training in the past three months & 1.2 & 1.3 & 1.2 \\
\hline Women & 49.7 & -- & -- \\
\hline \multicolumn{4}{|l|}{ Civil status } \\
\hline Single & 69.3 & 62.9 & 75.7 \\
\hline Married & 30.0 & 36.0 & 24.1 \\
\hline Divorced or in separation & 0.6 & 0.9 & 0.2 \\
\hline Widow & 0.1 & 0.2 & 0.0 \\
\hline Disabled & 1.0 & 0.8 & 1.1 \\
\hline \multicolumn{4}{|l|}{ Relation to the household head } \\
\hline Household head, man & 8.6 & -- & 17.1 \\
\hline Household head, single woman & 0.8 & 1.7 & -- \\
\hline Household head, non-single woman & 1.9 & 3.8 & -- \\
\hline Wife/husband & 12.3 & 22.6 & 2.0 \\
\hline Son/daughter, living with parents & 68.9 & 64.4 & 73.3 \\
\hline Son in law & 3.6 & 3.7 & 3.4 \\
\hline Other members of the household & 4.0 & 3.8 & 4.2 \\
\hline \multicolumn{4}{|l|}{ Main source of income of the household } \\
\hline Labour income & 63.9 & 65.2 & 62.5 \\
\hline Disability pension & 15.0 & 13.8 & 16.2 \\
\hline Unemployment benefit & 1.1 & 1.3 & 0.9 \\
\hline Non-earning source of income & 2.1 & 2.5 & 1.7 \\
\hline Private farm & 11.3 & 11.0 & 11.5 \\
\hline Self-employment & 6.7 & 6.2 & 7.1 \\
\hline \multicolumn{4}{|l|}{ Size of the place of residence } \\
\hline More than 100,000 inhabitants & 25.9 & 26.3 & 25.5 \\
\hline 50 through 99,000 inhabitants & 9.4 & 9.6 & 9.2 \\
\hline 20 through 49,000 inhabitants & 11.2 & 11.2 & 11.2 \\
\hline 10 through 19,000 inhabitants & 6.7 & 6.9 & 6.5 \\
\hline 5 through 9,000 inhabitants & 3.5 & 3.4 & 3.5 \\
\hline 0 through 4,000 inhabitants & 2.3 & 2.2 & 2.4 \\
\hline Living in rural areas & 41.1 & 40.3 & 41.8 \\
\hline Low unemployment voivodship ${ }^{1}$ & 11.2 & 13.6 & 8.7 \\
\hline Medium unemployment voivodship ${ }^{1}$ & 17.9 & 21.4 & 14.5 \\
\hline
\end{tabular}


High unemployment voivodship ${ }^{1}$

Expected lifetime earnings for high secondary school diploma Opportunity cost of studying

Note: ${ }^{1}$ the figures represent the unemployment rate

$3.2 \quad 4.9$


Table 2. Heckman PROBIT estimates of labour force participation (aged 15-30)

\begin{tabular}{|c|c|c|c|}
\hline Variable & All & Women & Men \\
\hline \multicolumn{4}{|l|}{$\begin{array}{l}\text { Education } \\
\text { (Reference category: primary or below) }\end{array}$} \\
\hline \multirow[t]{2}{*}{ University degree or above } & $1.1074 * * *$ & $1.0999 * * *$ & $0.9157 * * *$ \\
\hline & 0.089 & 0.1082 & 0.1664 \\
\hline \multirow[t]{2}{*}{ Post-secondary diploma } & $0.6578 * * *$ & $0.6784 * * *$ & 0.1931 \\
\hline & 0.0859 & 0.1035 & 0.1712 \\
\hline \multirow[t]{2}{*}{ General secondary school } & $0.48^{* * *}$ & $0.4826 * * *$ & $0.351 * * *$ \\
\hline & 0.0531 & 0.0733 & 0.0766 \\
\hline \multirow[t]{2}{*}{ Vocational secondary school } & $0.252 * * *$ & $0.3435 * * *$ & -0.0476 \\
\hline & 0.0664 & 0.0809 & 0.1443 \\
\hline \multirow[t]{2}{*}{ Low secondary school } & $0.34 * * *$ & $0.2148 * * *$ & $0.4075^{* * *}$ \\
\hline & 0.0516 & 0.0738 & 0.0917 \\
\hline \multirow[t]{2}{*}{ Age } & $0.2006 * * *$ & 0.0298 & $0.3575^{* * *}$ \\
\hline & 0.0687 & 0.0974 & 0.1304 \\
\hline \multirow[t]{2}{*}{$\operatorname{Age}^{\wedge} 2$} & $-0.0028 * *$ & 0.0006 & $-0.0059 * *$ \\
\hline & 0.0014 & 0.0019 & 0.0026 \\
\hline \multirow[t]{2}{*}{ Training in the past three months } & 0.1088 & 0.0434 & 0.1278 \\
\hline & 0.1091 & 0.1487 & 0.1754 \\
\hline \multirow[t]{2}{*}{ Women } & $-0.5293 * * *$ & -- & -- \\
\hline & 0.0334 & -- & -- \\
\hline \multicolumn{4}{|l|}{$\begin{array}{l}\text { Civil status } \\
\text { (Married) }\end{array}$} \\
\hline \multirow[t]{2}{*}{ Single } & $0.3126 * * *$ & $0.6275^{* * *}$ & $-0.2847 * * *$ \\
\hline & 0.0398 & 0.054 & 0.0701 \\
\hline \multirow[t]{2}{*}{ Divorced or in separation } & 0.0673 & 0.1071 & -0.2882 \\
\hline & 0.1493 & 0.1691 & 0.3239 \\
\hline \multirow[t]{2}{*}{ Widow } & -0.0367 & 0.1547 & -0.8777 \\
\hline & 0.3717 & 0.4049 & 0.5723 \\
\hline \multirow[t]{2}{*}{ Disabled } & $-0.3943 * * *$ & $-0.5855 * * *$ & -0.2644 \\
\hline & 0.133 & 0.1957 & 0.1877 \\
\hline \multicolumn{4}{|l|}{$\begin{array}{l}\text { Relation to the household head } \\
\text { (living with parents) }\end{array}$} \\
\hline \multirow[t]{2}{*}{ Household head, single man } & -0.0081 & -- & 0.1972 \\
\hline & 0.1604 & -- & 0.168 \\
\hline \multirow[t]{2}{*}{ Household head, non-single man } & $0.3093 * * *$ & -- & -0.0433 \\
\hline & 0.0918 & -- & 0.123 \\
\hline \multirow[t]{2}{*}{ Household head, single woman } & $-0.5653^{* * *}$ & $-0.4517 * * *$ & -- \\
\hline & 0.1446 & 0.105 & -- \\
\hline \multirow[t]{2}{*}{ Household head, non-single woman } & $-0.4363 * * *$ & $-0.8746 * * *$ & -- \\
\hline & 0.0949 & 0.1548 & -- \\
\hline \multicolumn{4}{|l|}{$\begin{array}{l}\text { Main source of income of the household } \\
\text { when the individual is not household head } \\
\text { (Private farm) }\end{array}$} \\
\hline \multirow[t]{2}{*}{ Labour income } & $-0.663 * * *$ & $-0.7613 * * *$ & $-0.5322 * * *$ \\
\hline & 0.0596 & 0.0752 & 0.0951 \\
\hline \multirow[t]{2}{*}{ Disability pension } & $-0.8418 * * *$ & $-0.8986 * * *$ & $-0.8079 * * *$ \\
\hline & 0.0662 & 0.0874 & 0.0978 \\
\hline \multirow[t]{2}{*}{ Unemployment benefit } & $-1.6599 * * *$ & $-1.7632 * * *$ & $-1.5173^{* * *}$ \\
\hline & 0.1627 & 0.2295 & 0.2601 \\
\hline Non-earning source of income & $-1.636 * * *$ & $-1.7674 * * *$ & $-1.5315^{* * *}$ \\
\hline & 0.1432 & 0.1888 & 0.2001 \\
\hline
\end{tabular}


Self-employment

Size of the place of residence (Living in rural areas)

More than 100,000 inhabitants

50 through 99,000 inhabitants

20 through 49,000 inhabitants

10 through 19,000 inhabitants

5 through 9,000 inhabitants

0 through 5,000 inhabitants

Constant
$-0.7361^{* * * *}$

0.0863

$-0.8699 * * *$

0.1103

$-0.5468 * * *$

0.1361

\begin{tabular}{rrr}
-0.0219 & 0.0815 & $-0.1402^{* *}$ \\
0.0404 & 0.054 & 0.0641 \\
$-0.1193^{* *}$ & -0.1003 & $-0.152^{*}$ \\
0.0548 & 0.0689 & 0.0862 \\
$-0.1348^{* * *}$ & -0.0139 & $-0.2744^{* * *}$ \\
0.0502 & 0.0669 & 0.0773 \\
-0.0905 & -0.0581 & -0.1228 \\
0.0611 & 0.0795 & 0.0939 \\
$-0.2326 * * *$ & -0.1122 & $-0.3458^{* * *}$ \\
0.0813 & 0.1068 & 0.1203 \\
$-0.2574 * *$ & -0.1133 & $-0.4123^{* * *}$ \\
0.1042 & 0.1425 & 0.1338 \\
$-2.2891^{* * *}$ & -0.6943 & $-3.8387 * *$ \\
0.8528 & 1.2208 & 1.6618 \\
\hline
\end{tabular}

\section{Selection equation}

Education

(Reference category: primary or below)

Post-secondary degree or above

General secondary school

Vocational secondary school

Low secondary school

Age

Age ${ }^{\wedge 2}$

Training in the past three months

Women

Civil status

(Married)

Single

Widow

Disabled

Relation to the household head

(living with parents)

Household head, single man

Household head, non-single man

Household head, single woman

\begin{tabular}{|c|c|c|}
\hline $1.8147 * * *$ & $1.8127 * * *$ & $1.698^{*}$ \\
\hline 0.4483 & 0.4093 & 0.9377 \\
\hline $1.7796^{* * *}$ & $1.8435^{* * *}$ & $1.8754 * *$ \\
\hline 0.4049 & 0.3703 & 0.8434 \\
\hline 0.7619* & 0.6389* & 0.9157 \\
\hline 0.4048 & 0.3727 & 0.8414 \\
\hline $2.116 * * *$ & $2.0692 * * *$ & $2.6014 * * *$ \\
\hline 0.3535 & 0.5709 & 0.5656 \\
\hline $0.7217^{* * *}$ & $0.7908^{* * *}$ & $0.5565 * * *$ \\
\hline 0.1035 & 0.1203 & 0.1998 \\
\hline$-0.0092 * * *$ & $-0.0118 * * *$ & -0.004 \\
\hline 0.0027 & 0.0029 & 0.0054 \\
\hline $1.3483^{* * *}$ & $1.3122 * * *$ & $1.392 * * *$ \\
\hline 0.217 & 0.3145 & 0.3133 \\
\hline-0.0566 & -- & -- \\
\hline 0.0366 & -- & -- \\
\hline$-1.1557 * * *$ & $-1.2508 * * *$ & $-0.7909 * * *$ \\
\hline 0.08 & 0.0895 & 0.1865 \\
\hline$-1.1117^{*}$ & -1.0233 & -- \\
\hline 0.6472 & 0.704 & -- \\
\hline $0.5998 * * *$ & $0.4197^{*}$ & $0.7348 * * *$ \\
\hline 0.1678 & 0.2467 & 0.2164 \\
\hline 0.0159 & -- & -0.0721 \\
\hline 0.1708 & -- & 0.1766 \\
\hline-0.0036 & -- & 0.2055 \\
\hline 0.2464 & -- & 0.3117 \\
\hline 0.3297 & $0.4376^{* *}$ & -- \\
\hline 0.2063 & 0.2139 & -- \\
\hline
\end{tabular}


Household head, non-single woman

Main source of income of the household when the individual is not household head (Private farm)

Labour income

Disability pension

Unemployment benefit

Non-earning source of income

Self-employment

Size of the place of residence (Living in rural areas)

More than 100,000 inhabitants

50 through 99,000 inhabitants

20 through 49,000 inhabitants

10 through 19,000 inhabitants

5 through 9,000 inhabitants

0 through 5,000 inhabitants

Regional unemployment of the under-30 (group U30(2)_1)

$\mathrm{U} 30(2) \_2$

U30(2)_3

U30(2)_4

U30(2)_5

Expected lifetime earnings of university degree

Expected lifetime earnings of high secondary school

Constant

Athrho

Rho

Wald test (indep. Equs) $($ rho $=0)$ : $\operatorname{chi} 2(1)=$

Nobs

Censored Nobs

Uncensored obs $\begin{array}{rrr}-0.0046 & 0.0718 & -- \\ 0.3619 & 0.3904 & --\end{array}$

$\begin{array}{rrr}-0.4058 * * * & -0.2552 * * * & -0.5169 * * * \\ 0.066 & 0.0906 & 0.0923 \\ -0.2953^{* * *} & -0.1389 & -0.4041^{* * *} \\ 0.0749 & 0.1055 & 0.1023 \\ 0.0058 & 0.1037 & 0.018 \\ 0.2155 & 0.2602 & 0.3452 \\ -0.2214 & -0.2606 & -0.1124 \\ 0.1612 & 0.2278 & 0.2126 \\ -0.4926 * * * & -0.305^{* *} & -0.6113^{* * *} \\ 0.0917 & 0.1267 & 0.1236\end{array}$

$-0.4979 * * * \quad-0.4253 * * *$

$-0.5164 * * *$

$\begin{array}{lll}0.0497 & 0.0703 & 0.0669\end{array}$

$-0.2532 * * * \quad-0.1766 \quad-0.2949 * * *$

$\begin{array}{lll}0.0641 & 0.0909 & 0.0885\end{array}$

$\begin{array}{lll}-0.4036 * * * & -0.3184 & -0.4279 * * *\end{array}$

$0.059 \quad 0.0825 \quad 0.0799$

$-0.2946 * * * \quad-0.2974 \quad-0.2414 * *$

$\begin{array}{lll}0.0741 & 0.1056 & 0.103\end{array}$

$\begin{array}{lll}-0.2856 * * * & -0.3835 & -0.2131\end{array}$

$\begin{array}{lll}0.0996 & 0.1249 & 0.1362\end{array}$

$\begin{array}{lll}-0.2187 * & -0.1222 & -0.2944 *\end{array}$

$\begin{array}{lll}0.1133 & 0.1371 & 0.1763\end{array}$

$\begin{array}{lll}0.0431 & 0.0636 & 0.0257\end{array}$

$\begin{array}{lll}0.0568 & 0.0812 & 0.0791\end{array}$

$0.1279 * * \quad 0.0186 \quad 0.1739 * *$

$\begin{array}{lll}0.0547 & 0.08 & 0.0746\end{array}$

$0.1724 * * * \quad 0.1605 * \quad 0.1636 * *$

$\begin{array}{lll}0.0566 & 0.0827 & 0.0803\end{array}$

$\begin{array}{lll}0.1197 * * & 0.1045 & 0.0956\end{array}$

$0.0585 \quad 0.0811 \quad 0.0901$

$-0.0852 * * * \quad-0.0582 * * \quad-0.1193 * *$

$\begin{array}{lll}0.0274 & 0.0246 & 0.0579\end{array}$

$\begin{array}{lll}-0.0523 & -0.0246 & -0.1137 * *\end{array}$

$\begin{array}{lll}0.0328 & 0.0535 & 0.0534\end{array}$

$-9.3367 * * * \quad-9.987 * * * \quad-8.2222 * * *$

\begin{tabular}{rrr}
1.0108 & 1.2487 & 1.843 \\
\hline $0.2111^{* * *}$ & -0.0817 & $0.4241^{* * *}$
\end{tabular}

$0.0741 \quad(0.1046) \quad(0.1889)$

$\begin{array}{lll}0.2081 & -0.0816 & 0.4004\end{array}$

\begin{tabular}{ccc}
$(0.0709)$ & $(0.1039)$ & $(0.1586)$ \\
\hline $8.13 * * *$ & 0.61 & $5.04 * *$
\end{tabular}

$($ Pr. $=0.00) \quad($ Pr. $=0.4346) \quad($ Pr. $=0.02)$

$16018 \quad 7956 \quad 8062$

$6122 \quad 3100 \quad 3022$

$9896 \quad 4856 \quad 5040$ 


\begin{tabular}{lccc} 
Log pseudo-likelihood & -8708 & -4599 & -3967 \\
Wald chi2 & 1295.75 & 553.37 & 420.88 \\
& $\operatorname{Pr}(0.00)$ & $\operatorname{Pr}(0.00)$ & $\operatorname{Pr}(0.00)$ \\
\hline
\end{tabular}

Note: $* p<0.1 ; * * p<0.05 ; * * * p<0.01$. Standard errors are between brackets.

The sample includes young people aged 15 through 30.

The dependent variable of the main equation takes a value of 1 for employment and 0 for joblessness (unemployment and inactivity). It is missing in case the respondent is involved into education. The dependent variable of the selection equation takes a value of 1 for selection in the main equation and zero for participation into education. For the definition of independent variables see Table A.I. in the Appendix.

The reference group in the main equation is constituted of married men aged 15-30, with primary education or below, living with their parents in rural voivodships and whose household lives out of labour income.

The Huber/White/sandwich estimator of variance and clustering by household are used to correct for heteroskedasticity.

Source: own elaboration on the Polish LFS. 
Table 3. Local unemployment and participation into education

\begin{tabular}{llllllr}
\hline & All & Women & Men & All & Women & Men \\
\hline Variable & & Model (1) & & \multicolumn{3}{c}{ Model (2) } \\
\hline U30(1)_2 & 0.0445 & 0.0284 & 0.0488 & 0.0127 & 0.0040 & 0.0120 \\
U30(1)_3 & 0.0453 & 0.0419 & 0.0129 & 0.0331 & 0.0370 & -0.0054 \\
U30(1)_4 & 0.0942 & 0.0297 & 0.1326 & 0.0990 & 0.0339 & 0.1376 \\
U30(1)_5 & $0.1233^{*}$ & 0.1204 & 0.1033 & $0.1300^{*}$ & 0.1262 & 0.1110 \\
U30(1)_6 & $0.1396^{*}$ & 0.1266 & 0.1399 & $0.1239^{*}$ & 0.1090 & 0.1278 \\
U30(1)_7 & $0.1663^{* *}$ & 0.1593 & 0.1419 & $0.1755^{* *}$ & 0.1529 & 0.1597 \\
U30(1)_8 & 0.0533 & 0.1445 & -0.0669 & 0.1070 & 0.1858 & -0.0091 \\
\hline U30(2)_2 & 0.0434 & 0.0693 & 0.0208 & 0.0564 & 0.0651 & 0.0541 \\
U30(2)_3 & $0.1240^{* *}$ & 0.0186 & $0.1735^{* *}$ & $0.1253^{* *}$ & -0.0115 & $0.2173^{* * *}$ \\
U30(2)_4 & $0.1734^{* * *}$ & $0.1630 * *$ & $0.1624 * *$ & $0.2124 * * *$ & $0.1758 * *$ & $0.2227 * * *$ \\
U30(2)_5 & $0.1183^{* *}$ & 0.1083 & 0.0832 & $0.1595^{* * *}$ & 0.1309 & 0.1365 \\
\hline
\end{tabular}

Note: $* p<0.1 ; * * p<0.05 ; * * * p<0.01$.

The coefficients have been obtained using the same estimation method as in Table 1 (see selection equation). Model (1) has the same specification as in Table 1, whereas the set of dummies relative to the city of residence is dropped from Model (2).

Note that for the first set of dummies the youth (15-30) unemployment rate is the same for men and women, whereas in the second set of estimates the youth unemployment rate is different for men and women. For a detailed definition of the two sets of dummies see Table A1 in the Appendix

Source: own elaboration on the Polish LFS. 


\section{Appendix A}

Table A1. Definition of independent variables

\begin{tabular}{|c|c|}
\hline Variables & Definition \\
\hline Educational variables & $\begin{array}{l}\text { Baseline - primary education or below } \\
\text { (years of education }=5 \text { or below) }\end{array}$ \\
\hline University education & University attainment (19) or above (Philosophy doctorate, 22) \\
\hline Post-secondary diploma & Post-secondary attainment (17) \\
\hline General high secondary & General secondary attainment (13) \\
\hline Vocational secondary & Vocational secondary attainment (10) \\
\hline Low secondary & Low secondary attainment ( 8$)$ \\
\hline $\begin{array}{l}\text { Low, medium and high } \\
\text { unemployment voivodships }\end{array}$ & $\begin{array}{l}\text { Voivodships have been ranked according to their unemployment rate. } \\
\text { Subsequently, they have been divided in three groups, each representing one } \\
\text { third of the sample. } \\
\text { In the Heckprobit estimates, the same procedure has been applied using the } \\
\text { unemployment rate of people aged } 15-30\end{array}$ \\
\hline Ureg30 & The voivodship youth (15-30) unemployment rate \\
\hline U30(1)_1 & $\begin{array}{l}\text { Voivodships included (the youth [15-30] unemployment rate is between } \\
\text { brackets): } 3 \text { [8.6], } 19 \text { [9.7], } 41 \text { [7.8], } 55 \text { [10.0], } 63 \text { [8.0], } 75 \text { [8.7] }\end{array}$ \\
\hline U30(1)_2 & 1 [12.6], 7 [12.8], 35 [13.3], 95 [13.4] \\
\hline U30(1)_3 & 11 [14.3], 25 [14.8], 27 [14.7], 59 [14.7], 71 [14.5] \\
\hline U30(1)_4 & 13 [17.8], 29 [17.6], 45 [15.6], 53 [17.3], 93 [15.6] \\
\hline U30(1)_5 & 9 [18.7], 43 [18.0], 61 [19.1], 83 [19.3], 85 [19.5], 87 [18.4] \\
\hline U30(1)_6 & $\begin{array}{l}5 \text { [20.7], } 21 \text { [21.9], } 31 \text { [22.0], } 39 \text { [21.8], } 47 \text { [20.5], } 57 \text { [22.4], } 73 \text { [20.4], } 97 \\
\text { [22.4] }\end{array}$ \\
\hline U30(1)_7 & 15 [23.8], 17 [24.2], 49 [24.1], 67 [24.6], 81 [24.8], 89 [24.4] \\
\hline U30(1)_8 & $\begin{array}{l}23 \text { [26.1], } 33 \text { [26.7], } 37 \text { [27.0], } 51 \text { [26.3], } 65 \text { [27.2], } 69 \text { [28.4], } 77 \text { [28.3], } 79 \\
\text { [28.3], } 91 \text { [29.9] }\end{array}$ \\
\hline U30(2)_1 & $\begin{array}{l}\text { Voivodships included: Men: 3, 11, 19, 27, 41, 55, 63, 75; Women: 3, 7, 19, 35, } \\
\text { 41, 45, 55, 63, 75, } 95 .\end{array}$ \\
\hline U30(2)_2 & $\begin{array}{l}\text { Men: 1, 7, 35, 53, 57, } 59 \text { and 71; Women: 1, 25, 47, 59, 61, 71, } 83 \text { and } \\
\text { 93. }\end{array}$ \\
\hline U30(2)_3 & $\begin{array}{l}\text { Men: 9, 13, 25, 29, 43, 85, 93, 95, 97; Women: 5, 11, 21, 27, 29, } 43 \text { and } \\
87 .\end{array}$ \\
\hline U30(2)_4 & $\begin{array}{l}\text { Men: 5, 15, 31, 37, 39, 45, 61, 73, 77, 79, 81, } 87 \text { and 89; Women: 9, 13, } \\
\text { 17, 31, 39, 49, 53, 67, 73, } 85 \text { and } 89 .\end{array}$ \\
\hline U30(2)_5 & $\begin{array}{l}\text { Men: 17, 21, 23, 33, 47, 49, 51, 65, 67, 69, } 83 \text { and 91; Women: 15, 23, } \\
\text { 33, 37, 51, 57, 65, 69, 77, 79, 81, 91and } 97 .\end{array}$ \\
\hline \multirow{4}{*}{$\begin{array}{l}\text { Expected lifetime earnings } \\
\text { for university degree }\end{array}$} & $\begin{array}{l}\text { Expected lifetime earnings have been computed for individuals aiming to attain } \\
\text { a university degree or a high secondary school diploma. Separate out of the } \\
\text { sample earnings equations have been estimated considering only the sample of } \\
\text { individuals holding a university degree and individuals holding a high school } \\
\text { diploma aged 31-60 if women and 31-65 if men (see Table A2). } \\
\text { Based on the results of these estimates, the expected lifetime earnings (ELE) } \\
\text { were computed for these two groups, as follows: }\end{array}$ \\
\hline & \multirow{2}{*}{$E L E_{i}=\frac{E E_{i}(31)}{(1-r)^{31-a g e}}+\ldots+\frac{E E_{i}(65)}{(1-r)^{65-a g e}}$} \\
\hline & \\
\hline & $\begin{array}{l}\text { where } i=1 \text { (University degree) and 2(high school diploma). ELE are calculated } \\
\text { by discounting the expected earnings (EE) for certain age by the interest rate. } \\
\text { Expected earnings are attained using means of the predicted value of earnings } \\
\text { for certain age, within the Heckit specifications. In turn, the average annual } \\
\text { interest rate, declared by the Warsaw Stock Exchange for the year 1997, is used } \\
\text { as a discount factor. }\end{array}$ \\
\hline $\begin{array}{l}\text { Expected lifetime earnings } \\
\text { for high secondary school diploma }\end{array}$ & See the explanation above \\
\hline Opportunity cost of studying & $\begin{array}{l}\text { The product of the average hourly wage and the probability to find employment } \\
\text { by age, defined for each individual according to his/her age. }\end{array}$ \\
\hline
\end{tabular}


Table A2. Earnings equations of individuals holding a university degree or a high school diploma, based on Maximum likelihood sample selection procedure (women aged 31-60; men aged 31-65)

\begin{tabular}{|c|c|c|c|c|}
\hline \multirow[t]{2}{*}{ Variables } & \multicolumn{2}{|c|}{ University graduates } & \multicolumn{2}{|c|}{ High school graduates } \\
\hline & $\mathrm{b}$ & s.e. & $\mathrm{b}$ & s.e. \\
\hline Work experience & -0.0107 & 0.0077 & -0.0007 & 0.005 \\
\hline Work experience squared & $0.0004^{* *}$ & 0.0002 & 0.0001 & 0.0001 \\
\hline Job tenure & 0.0002 & 0.0001 & $0.0004 * * *$ & 0.0001 \\
\hline Women & $-0.0754 * * *$ & 0.028 & $0.1894^{* * *}$ & 0.0133 \\
\hline \multicolumn{5}{|l|}{ Civil status (Reference category: Married): } \\
\hline Single & $-0.0834^{*}$ & 0.0459 & $-0.0668 *$ & 0.0268 \\
\hline Divorced or in separation & -0.0697 & 0.0666 & -0.0057 & 0.0301 \\
\hline Widow & -0.0469 & 0.0799 & 0.0441 & 0.0323 \\
\hline Training in the last three months & 0.067 & 0.074 & $0.1427 * * *$ & 0.0384 \\
\hline Temporary contract & -0.2154 & 0.2293 & $\stackrel{-}{-} 0.2702 * * *$ & 0.0498 \\
\hline \multicolumn{5}{|l|}{ Firm’s ownership (State sector) } \\
\hline Local authority & $0.0915 * * *$ & 0.0306 & $0.1285^{* * *}$ & 0.0263 \\
\hline Cooperative organisation & 0.0193 & 0.0855 & $-0.0954 * *$ & 0.0307 \\
\hline Private firm & $0.2144 * * *$ & 0.0552 & -0.0114 & 0.0201 \\
\hline \multicolumn{5}{|l|}{ Firm's size (More than 100 employees) } \\
\hline Less than 5 people & $-0.1788 * * *$ & 0.0668 & $\begin{array}{c}- \\
0.0719 * * *\end{array}$ & 0.0291 \\
\hline From 6 to 20 people & $-0.0813^{* *}$ & 0.0389 & -0.0322 & 0.0199 \\
\hline From 21 to 50 people & -0.0254 & 0.0408 & -0.011 & 0.0186 \\
\hline From 50 to 100 people & -0.0343 & 0.0364 & -0.0171 & 0.0212 \\
\hline Does not know the size of the firm & -0.0105 & 0.0862 & -0.0085 & 0.0563 \\
\hline \multicolumn{5}{|l|}{ Industry (State services) } \\
\hline Private farms & -0.0362 & 0.0829 & 0.0215 & 0.0394 \\
\hline Cooperative farms & & & $0.4313 * * *$ & 0.0338 \\
\hline Mining and Quarrying & 0.1549 & 0.1032 & $0.1893^{* * *}$ & 0.03 \\
\hline Manufacturing & -0.0724 & 0.0529 & -0.023 & 0.022 \\
\hline Electricity, gas and water supply & $0.1702 *$ & 0.0958 & $0.1513^{* * *}$ & 0.0346 \\
\hline Construction & -0.1222 & 0.0985 & 0.0147 & 0.0362 \\
\hline Trade and repair & $-0.2272 * * *$ & 0.0697 & $\begin{array}{c}- \\
0.0862 * * *\end{array}$ & 0.0285 \\
\hline Hotels and Restaurants & $-0.3110 * * *$ & 0.0941 & -0.0006 & 0.0842 \\
\hline Transports, storage and communication & 0.1044 & 0.0917 & $-0.0567 * *$ & 0.0233 \\
\hline Financial services & 0.0015 & 0.0513 & $0.0842 * *$ & 0.0257 \\
\hline Other services & $-0.2127 * * *$ & 0.0779 & 0.0202 & 0.0341 \\
\hline \multicolumn{5}{|l|}{ Region (Low unemployment voivodships) } \\
\hline Medium unemployment voivodships & $-0.0756^{* *}$ & 0.0359 & $\begin{array}{c}- \\
0.0801 * * *\end{array}$ & 0.0163 \\
\hline High unemployment voivodships & -0.0459 & 0.0341 & $\begin{array}{c}- \\
0.0605^{* * *}\end{array}$ & 0.0158 \\
\hline Constant & $2.0119 * * *$ & 0.0882 & $1.5486 * * *$ & 0.063 \\
\hline \multicolumn{5}{|l|}{ Selection equation } \\
\hline Work experience & 0.0254 & 0.0158 & $0.0831^{* * *}$ & 0.0108 \\
\hline Work experience squared & $-0.0010^{* * *}$ & 0.0004 & $\begin{array}{c}- \\
0.0019 * * *\end{array}$ & 0.0002 \\
\hline Women & $0.3002 * * *$ & 0.111 & $0.2202 * * *$ & 0.0592 \\
\hline
\end{tabular}


Civil status (Married):

Single

Divorced

$-0.28 *$

0.1494

$0.2347 * * *$

0.093

Widow

0.1583

0.1394

$-0.1363 *$

0.0771

Training in the last three months

$-0.0498$

0.1712

$-0.1455^{*}$

0.0841

Regions (Low unemployment voivodships)

Medium unemployment voivodships

$0.4032 * *$

0.1869

0.079

0.1333

High unemployment voivodships

$\begin{array}{llll}0.5379 * * * & 0.067 & 0.3304 * * * & 0.0386\end{array}$

Relation to the household head

(Wife/husband)

Household head (man)

Household head (single woman)

0.1729

0.112

$0.341^{* * *}$

0.0616

Household head (non single woman)

$0.6433 * * *$

0.2011

$-0.0383$

0.1343

Other type of relation (sun/daughter; uncle; grands)

$-0.2236 * *$

0.0966

$0.2311^{* * *}$

0.0501

$0.277^{*}$

0.1483

$0.1848 * * *$

0.0738

Living in rural areas

$-0.0716$

0.0754

0.0368

Main source of income of the household (Labour income)

Disability pension

Unemployment benefit

$-1.0105 * * *$

0.1085

$0.2921 * * *$

Non earning source of income

$-1.1812^{* *} \quad 0.557$

$0.8216^{* * *}$

0.054

Self employment

$-7.1918 * * * \quad 0.1863$

$1.4748^{* * *}$

0.2657

$-1.1166 * * *$

0.0902

$1.6844 * * *$

0.26

Constant

$-0.3907 * *$

0.1875

$-1.244^{* * *}$

0.059

Athrho

$-0.1448$

0.087

$1.1432 * * *$

0.148

Lnsigma

Rho

Sigma

$-0.8304^{* * *} \quad 0.0352$

$0.2585^{* * *}$

0.0445

Lambda

$-0.1438$

$1.0297 * * *$

0.0277

Nobs

0.4359

0.0852

$-0.2529$

0.0416

$-0.0627$

0.0153

0.3571

0.0099

Censored Nobs

2773

$-0.0903$

0.0155

Uncensored obs

Wald test (indep. Equs) $($ rho $=0)$ : chi2(1) =

Wald chi2(29)

8310
$1523 \quad 4952$

1250

3358

$2.77 \quad 33.77$

$(\operatorname{Pr}=0.096)$

$(\operatorname{Pr}=0.0)$

Log pseudo-likelihood

$-2388.356$

$-6186.593$

Note: $* p<0.1$; ** $p<0.05$; *** $p<0.01$.

The sample includes men aged 31 through 65 and women aged 31 through 60 . The dependent variable is the log of hourly wages (monthly wages divided by weekly hours of work times 4.3).

For the definition of the independent variables see Table A.I in the Appendix.

The reference group in the main equation is constituted of married men with a permanent labour contract in a large organisation (more than 100 employees) in the state service sector, leaving in a high unemployment voivodship. The reference group in the selection equation is made of married men living in a high unemployment voivodship, who are not household head, whose main source of income is neither a disability pension, nor an unemployment benefit.

The Huber/White/sandwich estimator of variance and clustering by household are used to correct for heteroskedasticity.

Source: own elaboration on the Polish LFS. 